\title{
The Relationship between Body Mass Index and Bone Mineral Density in elderly women referred to Quality of Life Control and Health clinic
}

\author{
Mortazavi S.AM ${ }^{1}$, AkbariKamrani AA ${ }^{* 2}$, Sahaf $\mathrm{R}^{3}$
}

\begin{abstract}
Introduction and purpose: Osteoporosis and obesity are a major problem that their prevalence is increasing. Obesity is a risk factor for large number of diseases such as, cardiovascular and metabolic diseases.Several studies have investigated the association between body mass index (BMI) and bone mineral density (BMD) and indicate, it has protective effect on bone loss however the results are inconsistent. The aim of this study wasevaluation of relationship between Body Mass Index and Bone Mineral Density in Elderly women refers to quality of life control and health clinic of Khatam-ol-Anbiya Hospital in 2012-2013.
\end{abstract}

Materials and Methods: This sectional study has been done on 139 elderly women aged 60 and over inquality of life control and health clinic of Khatam-ol- Anbiya Hospital inTehran city, Iran. Demographic data collected by questionnaire. Weight and height were measured. Body massindex (BMI) was calculated and bone mineral density (BMD) was measured by DEXA scan in lumbar spine and femoral bone.

Findings: The study population included 139 elderly women with mean age $70.1 \pm 6.2$ years old. The mean BMI in these groups was $26.6 \pm 0.7 \mathrm{~kg} / \mathrm{m}^{2}$. In this study, data analyses of femoral bone and lumbar spine showed that aging related by decrease of BMI and bone mineral content (BMC). BMI has significant positive relationship with $\mathrm{BMC}(\mathrm{p}=0.01)$ that this relationship was strongest in femoral neck $(\mathrm{p}=0.001)$. In overall the strongest relationship of femoral bone and lumbar spine BMC was with BMI $((\mathrm{r}=0.292, \mathrm{P}=0.005)$ and $(\mathrm{r}=0.232, \mathrm{P}=0.005))$. Also, there was a positive significant association between $\mathrm{BMI}$ and mean T-Scorein femur and lumbar spine region $((\mathrm{r}=0.492, \mathrm{P}=0.01)$ and $(\mathrm{r}=0.388, \mathrm{P}=0.001))$.

Conclusions: These data indicate that BMI is associated with bone mass of femur and vertebrae and obesity decreased the risk for osteoporosis.

Key Words: Bone Mineral Density, Body Mass Index, Elderly.

Received: 2016/01/24

Accepted: 2016/05/22

Copyright $\odot 2018$ Quarterly Journal of Geriatric Nursing.This is an open-access article distributed under the terms of the Creative Commons Attribution international 4.0 International License(http://creativecommons.org/licenses/by /4.0/) which permits copy and redistribute the material, in any medium or format, provided the original work is properly cited.

1 - MD, MpH in Gerontology. Iranian Research Center on Aging and Department of aging, University of Social Welfare and Rehabilitation, Tehran, Iran

2 - MD, Internal Medicine Specialist, Fellowship of Geriatrics. Iranian Research Center on Aging and Department

of aging, University of Social Welfare and Rehabilitation, Tehran, Iran.

(Corresponding Author):E-mail: akbarikamrani@uswr.ac.ir

3 - MD, MHSc, PhD in Gerontology. Iranian Research Center on Aging and Department of aging, University of

Social Welfare and Rehabilitation, Tehran, Iran 


\section{ارتباط بين شاخص توده بدنى با تراكم استخوان در زنان سالمند مراجعه كننده به كلينيك

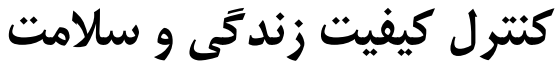

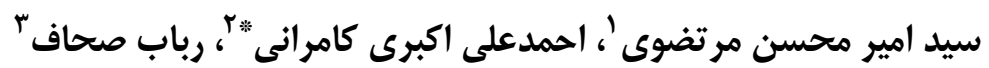

تاريخ دريافت مقاله:

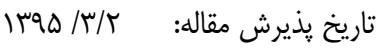

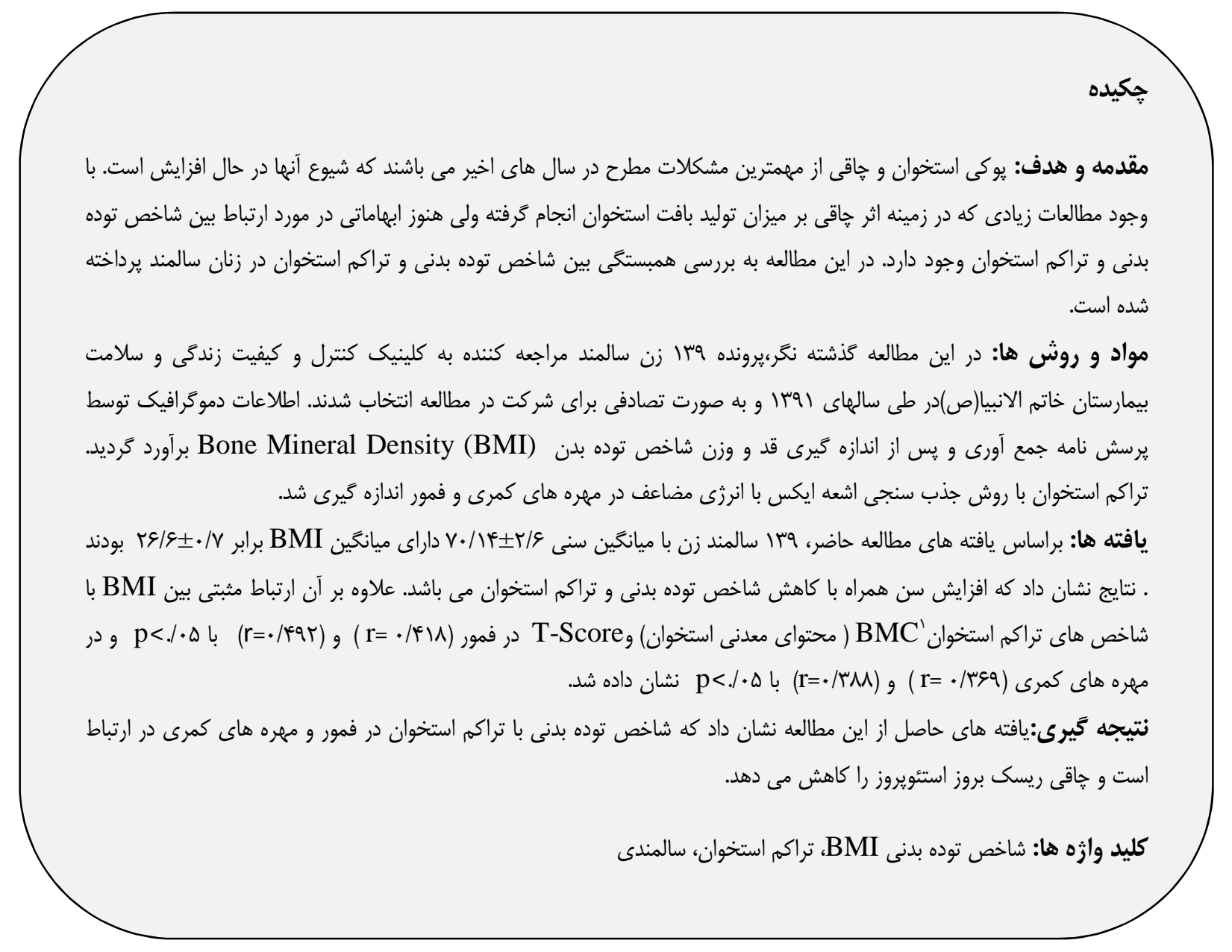

ا- مركز تحقيقات سالمندى و كروه آموزشى سالمندى ، دانشكاه علوم بهزيستى و توانبخشى،تهران ،ايران

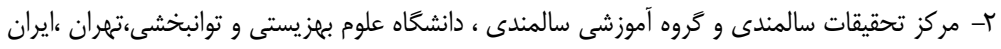
(نويسنده مسؤول). پֶست الكترونيكى: akbarikamrani@uswr.ac.ir

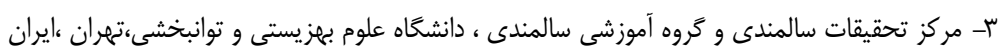


به انسولين باعث افزايش انسولين پإسما، توليــــــالاى هورمـون هاى جنسى آندروثن و استروزن از تخمدان و كاهش يروتئين هاى كبد كه در ارتباط با هورمون هاى جنسى هستند، مسى گـردد. ايـن تغييرات موجب افزايش استروزن و در نتيجه تـوده اسـتخوانى بــــ واسطه كاهش عملكرد سلول هاى استئوكلاست (جذب اسـتخوان) و افزايش فعاليت استئوبلاست ها (سنتز اسـتخوان) مـى گــدد(^). بررسى ها همجنين نشان داده كه افزايش توده بــنى بــه صـورت مستقيه و غير مستقيم از مسير ملكول هاى مشتق از بافت هربسى همجِون لِتين و ادييونكتين بر متابوليسم استخوان اثر دارد(9). بـــ اين ترتيب كه لِتين اثر منفـى و ادييـونكتين اثر مثبـت بـر تـوده

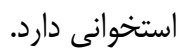

نتـايج مطالعـات انجـام شـده دربـاره ارتبـاط بـين BMI و و متناقض مى باشد. بــه عنـوان مثـال، در مطالعـه اى اثـر مثبت خاقى بـر شـاخص BMD مهـره هـاى كمـرى، حـردن و تروكانتر فمور تعيين شد(·). همجنين در مطالعه اى جـاقى بـهـ عنوان عامل محافظت كننده در برابر يوكى استخوان شـناخته شـــ (I) (1). در بررسى ديخًرى نيز ارتباط مثبت و معنى دار بين BMD مهره هاى كمرى و شاخص توده بدنى نشـان داده شـــ. در مقابـل يافته هاى فوق، بررسى ها ديگر نشان داده انـد كـه تـوده هربسى بيش از حد ممكن است باعث كاهش توده استخوانى گـردد ( rا-

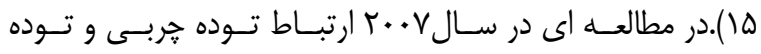
استخوانى را به صورت مثبت ارزيابى كرد. اين در حالى است كه در ادامه با حذف اثر مكانيكى بر وزن كل بدن ، توده جربى همبستىى

1. Body Mass Index
يوكى استخوان و اضافه وزن مشـكل بـزرى بهداشـت جهـانى در سال هاى اخير مطرح شده است كه شيوع آنها در حال افزايش مى باشد. سازمان بهداشت جهانى (WHO) از اسـتئويروز بـهـ عنـوان يكى از ههار بيمارى شايع جهان نام ببرد (Г). ايـن بيمـارى شـايع ترين بيمارى متابوليك استخوان است كه استخوان هـا را نـازى و مستعد شكستخى مى كنـــ (ب). عوامـل مختلفـى در ايجـاد يـوكى استخوان دخالت دارند كه بعضى غير قابل كنتـرل ( سـن، جـنس، نزاد، سابقه فاميلى، يائسگى) و برخى قابل كنترل ( ورزش نكردن، كمبود كلسيم و ويتامين D در رزيم غذايى، سـيگار و الكـل) مسى باشند (أ). هاقى به عنوان ريسك فاكتور در بيمارى هاى قلبس عروقى و متابوليك محسوب مى شود با اين وجـود مطالعـه ایى در اين زمينه نشان داده كه جاقى بر روى جذب استخوان اثر حمـايتى دارد. مكانيسم دقيق خاقى بر جذب استخوان شناسايى نشده اسـت ولى توضيحات اندى در اين زمينه نقـش دوكانـهـ آن را بيـان مسى دارد. نتايج بــه دسـت آمــه از مطالعـات نشـان داده كـه افـزايش شاخص توده بدنى منجر به تحليل نيرو و فشـار اضـافى بـر تـوده استخوانى شده و اين امر با سنتز بافت استخوان همـراه اسـت (ه). در حالى كه يافته هاى مطالعه اى ديكر، حضور بافت خربسى را در ارتباط با افزايش سيتوكين هاى التهابى و فاكتورهاى نكروز تومـور مى دانند، كه اين امر منجر به جذب بافت استخوان مى گردد((). سلول هاى بافت جربى منابع اصلى توليد هورمون جنسى استروزن در زنان در دوره يائسخى هستند. افزايش بافـت خربسى بـه دنبـال افزايش توليد استروزن سبب كاهش عملكـرد استئوكلاسـت هـاو و كاهش جذب استخوانى مى شود (VV). بعلاوه، :اقى با ايجاد مقاومت 
BMI $\left(\mathrm{kg} / \mathrm{m}^{2}\right)=$ Weight بر اساس فرمول BMI ميزان محاسـبه گر ديسـ. بـر اسـاس معيـار $(\mathrm{kg}) \div$ Height $\left(\mathrm{m}^{2}\right)$

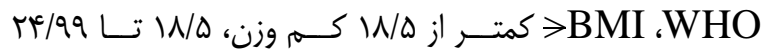

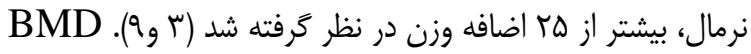
با روش جذب سنجى اشعه ايكس با انـرزى مضـاعف (DEXA) توسط دانسيتومتر در گردن استخوان فمـور و مهـره هـاى كمـرى اندازه كيرى شد و نتيجه بـر اسـاس T-Score بيـان (L1-L4) كرديد. بر طبق تعريف سـازمان بهداشـت جهـانى، كـاهش تـراكم استخوان به ميزان ه/r|نحـراف معيـار يـايين تـر از حـداكثر تـوده

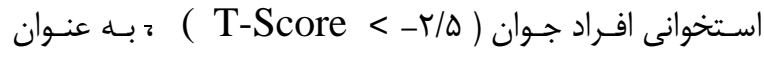

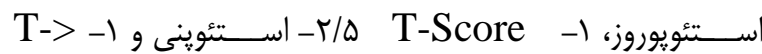

$$
\text { Score }
$$
هِ از جمع آورى اطلاعات از طريـق آمـار توصـيفى ميـانگين و

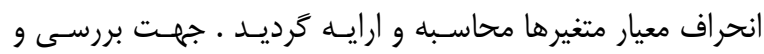
مقايسـه بـين خـروه هـاى سـنى از آزمـون ا تسـت و از ضـريب همبستخى ييرسون جهـت ارتبـاط ميـان متغيرهـاى BMI و T T Score

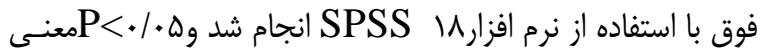
دار در نظر كَرفته شد.

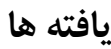

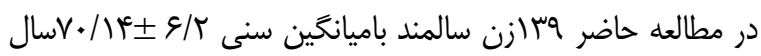
شركت نمودند.حداقل سن افراد شركت كننده •و سـال و حـداكثر سن 19 سال بود. به منظور بررسى تغيــات تـراكم اسـتخوانى بــا افزايش سن، براى اين مراجعه كنندًَان گَروه هـاى سـنى تعريـف
منفى با توده استخوانى نشان داد و در واقع مى توان عنـوان نمـود كه توده جربى اثر عكس بر سنتز استخوان دارد(1). بعلاوه، Hsu و Venners (سال צ..+1) را بطه منفى بين درصد توده هربى

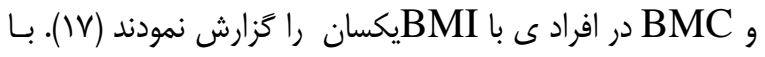
توجه به اين نتايج ضدو نقيض ، هدف اصلى مطالعه حاضر بررسى ارتباط بين شاخص توده بدنى و تراكم مواد معدنى بود.

\section{مواد و روش ها}

مطالعه كنونى توصيفى - تحليلى و از نوع كَذشته نخر مى باشد. به اين ترتيب كه اين مطالعه توصيفى از نـوع غيرمداخلـه اى بـوده و داده هاى لازم از يرونده بيمار كسب شـد. ايـن تحقيـق در كميتـهـ اخلاق دانشگاه علوم بهزيستى و توانبخشى تاييد شد. زنان سالمند مراجعه كننده به كلينيى كنترل كيفيت و سلامت بيمارستان خاتم

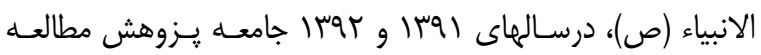
حاضر را تشكيل مى دادنـد. از بـين ايـن افـراد، وسا نفــر صـورت تصادفى براى شركت در ايـن مطالعـه انتخــاب شــند. معيارهـاى خروج از مطالعه شامل اختلال ذهنى و روانس، نقـص در نـواحى ستون فقرات و لكَن و اندام تحتانى، وزن بـالاتر از • rا كيلـوگرم، نازايى و حاملگى و شيردهى، نارسايى كليه بـهـ صـورت حساد و يـا مزمن، نارسايى ييشرفته كبدى، ابتلا بـه هرنـوع سـرطان، اسـمال مزمن (بيش از r هفته) يا بيمارى سوء تغذيه، مصرف ويتـامين D

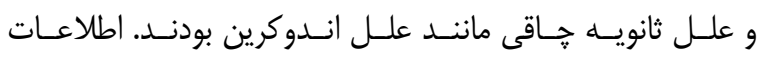
دموكرا افيك افراد ثبت شد. قد (بـهـ سـانتى متــر) توسـط قـــــــن ايستاده و وزن ( به كيلوكَرم) توسط ترازوى ديجيتال seca (آلمان - مدل Vعq) با حداقل لباس و بــدون كفـش انـدازه گيـرى شـــ. 


$$
\text { شد كه يافته هاى تن سنجى اين افراد در جدول ( نشان داده شـده است. }
$$

جدول ا. يافته هاى تن سنجى زنان سالمند مراجعه كننده به كلينيك كنترل كيفيت و سلامت بيمارستان خاتم الانبياء (ص)، درسالهاى اوسا و זوسا بر حسب سه كروه سنى. :تمامى اعداد مربوط به جدول به صورت ميانكين| نحراف معيار بيان شده اند.

\begin{tabular}{|c|c|c|c|c|}
\hline (كيلو نَرم بر مترمر بدريع) & (سانتى متر) & (كيلو & تعداد & كروه سنى (سال) \\
\hline$r q / q \pm \cdot / r$ & $|Q F / G \pm \cdot / V|$ & $V / / \mathscr{q} \pm 1 / \mathcal{G}$ & st & $9 \cdot-99$ \\
\hline$r q \pm \cdot / v$ & $\mid Q T / T \pm \cdot / V$ & $9 V / \Delta \pm 1 / V$ & $a^{4}$ & $r \cdot-v q$ \\
\hline$r \varphi / \Delta \pm I / r$ & $10 f \pm 1 / \Lambda$ & 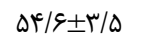 & 11 & $1 \cdot-19$ \\
\hline$r \xi / \xi \pm \cdot / V$ & $\mid \Delta T / \Psi \pm \cdot / \Lambda$ & $S N / \Psi \pm \Psi / K$ & 149 & ميانكَين كل \\
\hline
\end{tabular}

بررسى ميانخين BMC در مهره هـاى كمـرى L12 L2، L3 و

L4 در زنان مورد مطالعه نشان مى دهد كه محتواى مواد معـدنى

از مهره اول به سمت مهره جهارم افزايش مى يابد و اين تفاوت از

لحاظ آمارى معنى دار است. كمترين ميزان BMC در مهره دوم و

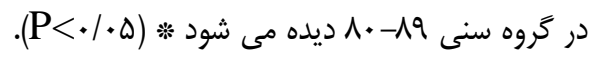

أزمون آمارى t تست رابطه بين افزايش سن بـا كـاهش BMI در گروه هاى سنى مختلف نشان مى دهد. كه اين كاهش در كروه

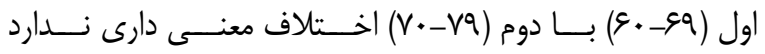

(P>/F)

BMC Score in experimental group (Female) in various age

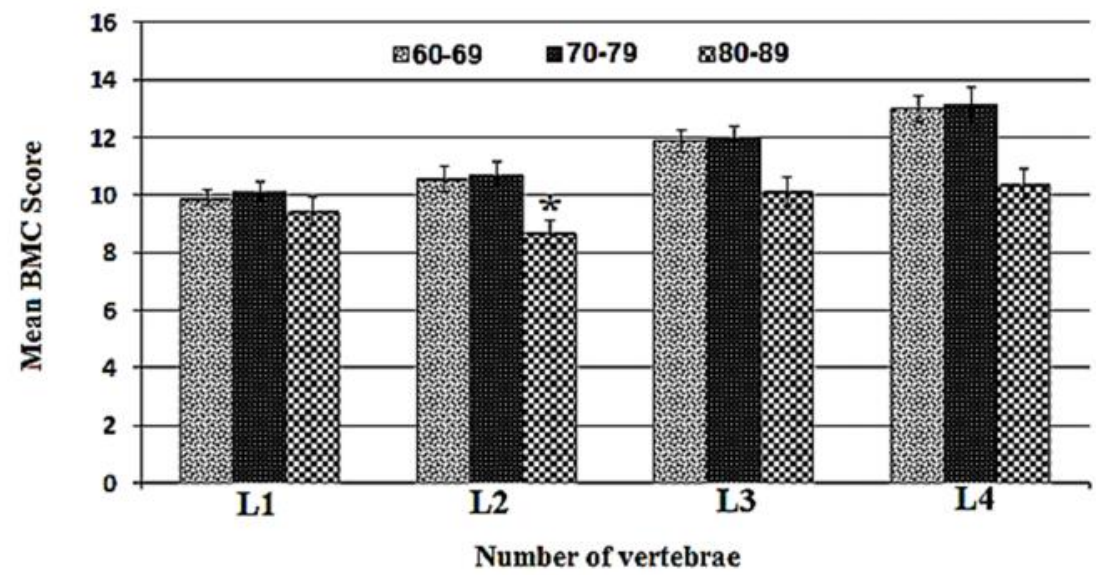

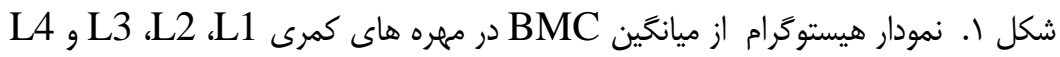
بيشترين محتواى مواد معدنى در انــام تحتـانى در تنـه اسـتخوان فمور متمركز مى باشد. در بين سـهـ كَروه ســى بــا افزايش سـن 


\section{BMC Score Femur (Female)}

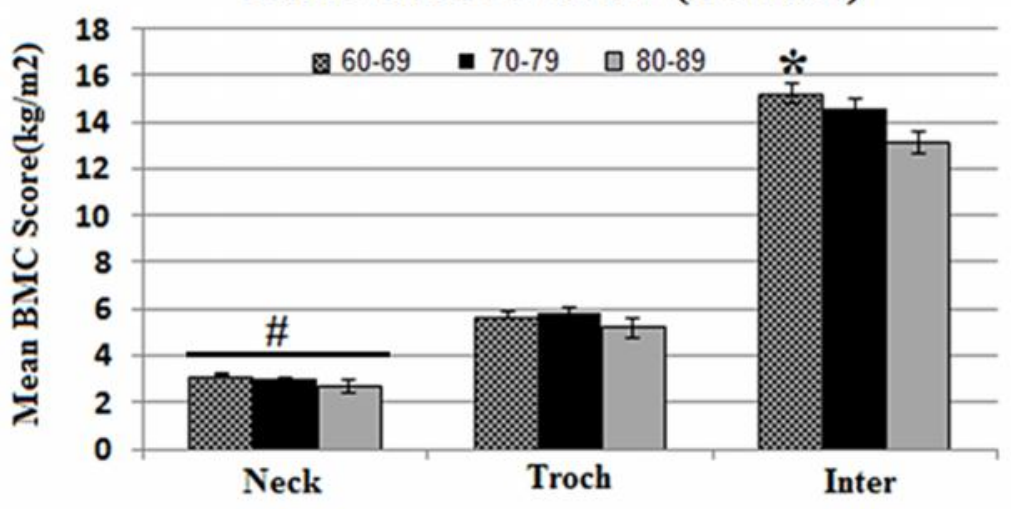

شكل r. نمودار هيستوگرام ميانخين BMC در نواحى گردن ، تروكانتر بزرگ و تنه استخوان فمور

كروه سنى 9צ-•• ميانخين T-Score در استخوان فمـور زنـان

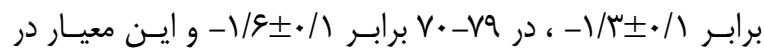

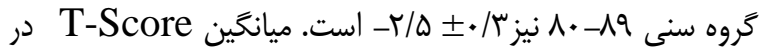

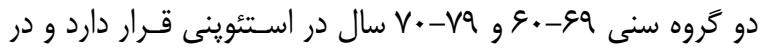

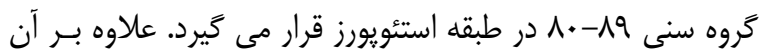

اختلاف معيار T-Score در گروه سنى 19-••^ با دوخـروه ديخـر

$$
\text { تفاوت معنى دارى را نشان داد. }
$$

همجֶنين نتايج به دست آمده نشان داد كه در گـروه سـنى 99-• ميانكين T-Score در مهره هاى كمرى زنان برابر / /

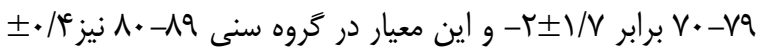

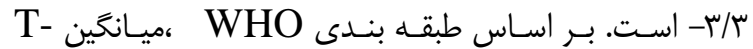
Score

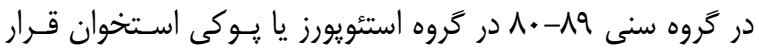
مى گيرد. علاوه بر آن اختلاف معيـار T-Score در گـروه سـنى

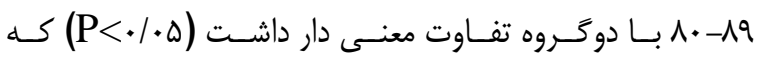
نشاندهنده كاهش ميزان T-Score با افزايش سن مى باشـد. در 


\section{T-Score in Femur and Vertebra}

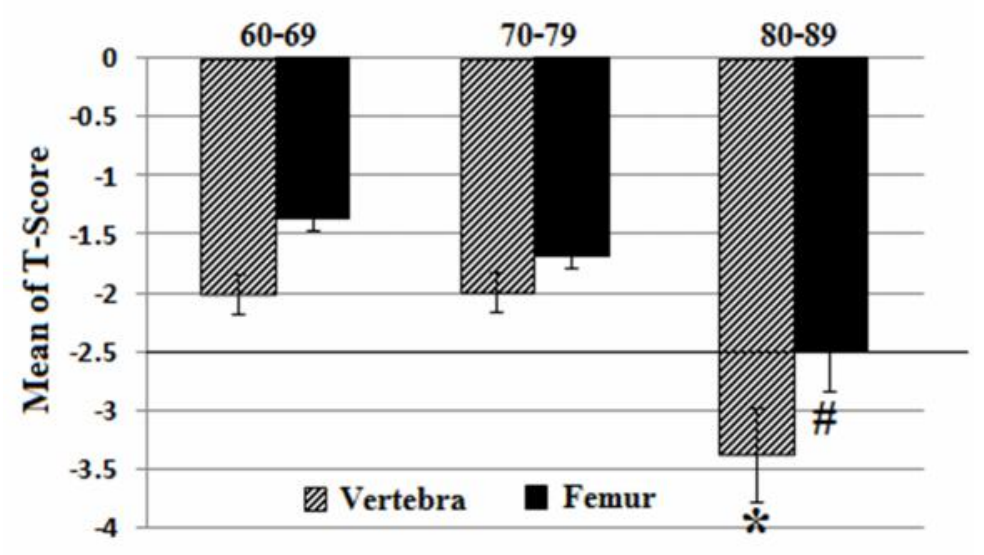

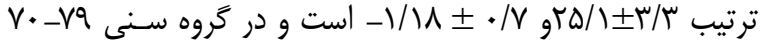

به ترتيب ع/ تراكم استخوان در سنين متفاوت و BMI يكسان نشان مى دهـــ كه با افزايش سن BMC كاهش مى يابد و علاوه بـر آن معيـار T-Score به سمت استئويورز يعنى كمتر از ه/ T- ييش مى رود. نتايج آزمون همبستخى ييرسون ارتباط معنى دار بين شاخص توده بدنى با BMC (

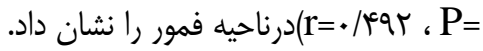

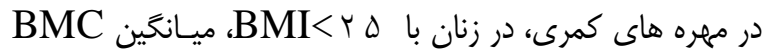

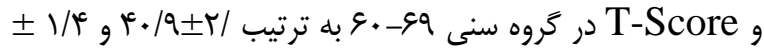
و

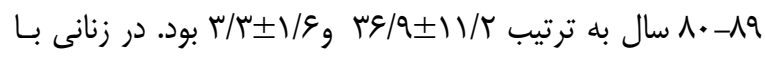
B 9 9- • 9 به ترتيسب ترتيــ / / T-Score gMC BMC

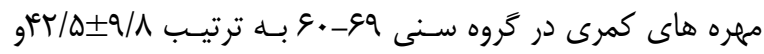

شكل س. نمودار هيستوگرام از ميانخين T-Score استخوان فمور و مهره هاى كمرى در زنان بر حسب سه كَروه سـنى ** كمتـرين ميانكَين T-Score در كروه سـى 19-••^در ناحيـه كمـرى \# كمترين ميانخين T-Score را در گروه سـنى 19-• •1 در ناحيـ فمور به منظور بررسى ارتباط بين شاخص هاى تراكم استخوان و توده بدنى افراد مورد آزمون در هر گروه سنى، BMI به سه گروه

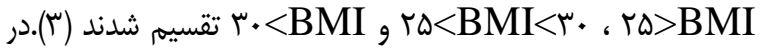

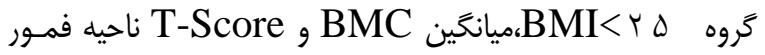
در تروه سنى وع-. ع به ترتيب ه/ سنى به ترتيب در گروه با • T-Score

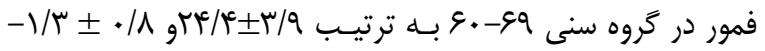

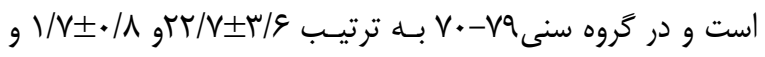

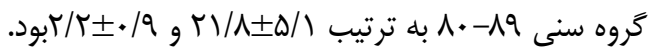

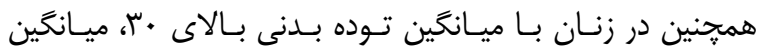
ن-Score و BMC 
آزمون همبستخى ييرسون، ارتباط معنى دار بين شاخص توده بدنى

T-Score $\quad$ g $(\mathrm{r}=0.232, \mathrm{P}=0.005) \quad \mathrm{BMC}\llcorner$

(P=0.001, r=0.388)

هربى و يا توده بدون خربى با تراكم استخوان رابطه مسـتقيم دارد

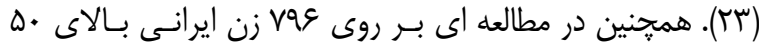
سال، افراد با شاخص توده بدنى كمتر از مك نسـبت بـهـ سـايرين ،

Gallegos Uribe استئويروز بيشترى را نشان دادند (T). (سال1991) در طى مطالعه اي بـر روى rآ9 زن مكزيكى نشـان دادند BMD لكَن و كمر در زنان بزركتر از هـ سـال كـه اضـافه وزن داشتند به طـور معنى دارى از زنـانى كـه BMI يـايين تـر داشتند،يشتر است (ما). همحِنين مطالعـات Bener و همكـاران در آمريكاو Paniagua همكاران در كانادا نيـز ارتبــاط مثبـت تراكم معدنى استخوان با شاخص توده بدنى را تاييـد كردنـد(عب و

اضافه وزن ممكن است با افزايش استروزن، تبـديل آندرسـتنديون در سلول هاى جربى و كاهش غلظت گلوبولين هاى متصل شونده به هورمون هاى جنسى از زنان يائسه در برابر از دست رفتن بافت استخوانى محافظت كند. از طرفى اثر بار وزن بدن و تـوده هربسى مى تواند عامل ديخرى جهت تحريك استخوان سازى باشد. علاوه بر اين بافت هربى به عنوان يك منبع ذخيره كننده هورمون هـاى

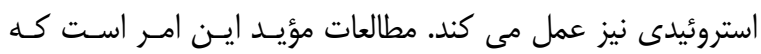
استروزن داراى اثرات القاء كننده در بيان خن هاى استئوبلاسـت را

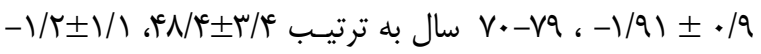
بود. مقايسه بين شاخص هاى تراكم استخوان مهره هـاى كمـرى در سنين متفاوت و BMI يكسان نيز نشـان داد كـهـ بـا افـزايش سن، BMC مو معيار T-Score كاهش مى يابد. بر اساس نتايج

\section{بحث و نتيجه تَيرى}

هدف اصلى اين مطالعه بررسى رابطه شاخص توده بــنى وتـراكم استخوان بود. به طور كلى در اين مطالعه همبسـتخى مثبتى بـين شاخص توده بدنى و تراكم استخوان در زنان مـورد مطالعهـ وجـود داشت. با افـزايش سـن و كـاهش BMI اسـتئوينى و اسـتئويروز افزايش يافت. بين BMI بـا تـراكم معـدنى اسـتخوان در هـر دو ناحيه همبستخى مثبت معنى دارى وجود داشته كه اين همبسـتخى در گردن فمور قوى تر بوده است. در مطالعه اى كه در سال هـ+r در استراليا انجام شد نيز ارتباط مثبـت معنسى دارى بـين BMI و BMD حــردن فمــور و ســتون فقــرات وجــود داشــت(19). همجنين Zhao و همكارانش با مطالعه بر روى افراد جينـى نـزاد سفيد يوست بيان نمودنــد كـه وزن و BMI بـا تـوده اسـتخوانى

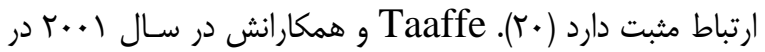
يك مطالعه كوهورت روى زنـان و مـردان سـفيد و سـياه يوسـت نتيجه كَرفتند كه توده جربى با دانسيته اسـتخوان رابطـه مثبـت و معنـادارى دارد (آr). از طرفى Bakker و همكـارانش در سـال ץ ..r نيز با كشف رابطه مستقيم و مثبت بين توده بدن و دانسـيته استخوان دريافتند كه BMI به عنوان پـيش بينـى كنـــه تـراكم استخوان مى باشد(r). MacInnis و همكارانش در سال r.+r با بررسى زنان سالمند دريافتند كه توده بدنى جه از نظر بافت 
علاوه بر آن بررسى هاى انجام شده در مطالعه حاضر نشان داد كه شاخص T-Score در ناحيه فمور با افزايش سن به سمت كاهش تراكم استخوان ، استئوينى و استئويرز ييش مى رود كه البتـه ايـن

نتايج در مورد مهره هاى كمرى بيشتر مشاهده شد. اين يافته هـا نيز در راستاى نتايج ساير مطالعاتى است كه در كذشته انجام شـده است و بيان مى دارد با افزايش سن احتمال بروز استئوينى افزايش مى يابد و از طرفى اين خطر در زنان به علت فرآينـد هـايى جـون

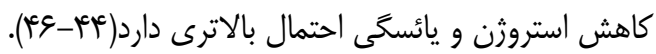
بررسى ارتباط بين BMI و فاكتور T-Score ، BMC نشان داد كه در ناحيه فمور با افـزايش BMI سـطح BMC بطـور معنى دارى افزايش و سطح T-Score كاهش يافته همجنين مطالعات بر روى مهره كمرى نيز نشان داد كـهـ بـا افززايش BMI سـطح Toth در مهره هاى كمرى افـزايش يافت. در مطالعـه BMC نشان داده شد شاخص توده بدنى فاكتور تعيين كننده ای در تراكم

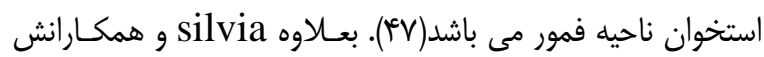
كزارش نمودند كه شاخص توده بدنى عامل اصلى تراكم استخوان فمور است (^^^). با اين وجود مطالعاتى نيـز اثـر BMI بــر تـراكم استخوان را مثبت ارزيابى كردند (QT-Yq). نتايج اين يزوهش حاكى از آن است كـه شـاخص تـوده بــنى بــا تراكم استخوان در فمور و مهره هـاى كمـرى در ارتبـاط اسـت و קاقى ريسك بروز استئويروز را كاهش مى دهـــ. همجنـين نتـايج كلى بررسى ميانگَين T-Score اسـتخوان فمـور و مهـره هـاى كمرى در زنان تاييد كننده اين امر است كه با افـزايش سـن ايـن شاخص در هر دو ناحيه كاهش مسى يابــــ و در نتيجـه مسى توانـــ احتمال بروز شكستخى را افزايش دهد.

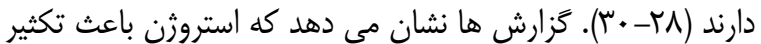
DNA كردد و براى استئوبلاست به صورت يك عامل ميتوزن عمل مسى كند. اين هورمون موجب افزايش بيان آلكـالين فسـفاتاز و كـلاثن تيــ I مـى گَــدد در حـالى كـهـ نبـود آن موجـب افـزايش بيـان استئوكلسين همراه با كلاثن مسى حـردد (اسب-سّ). عـلاوه بـر آن استروثن موجب تحريك گيرنده هاى بيان كننده هورمـون رشـدو يروزسترون مى گــردد و از طرفى بـا تنظـيم هورمـون PTH در استئوبلاست ها موجب افزايش فاكتورهاى رشد مى گردد و باعـث كاهش جذب استخوان و اثر آنزيم هـاى بروتئوليتيـى مسى شـود.

نتايج برخى از يافته ها نيز با اين داده ها متناقض است. در مطالعه اى نشان داده شد كه جاقى به صورت معنى دارى خطر اسـتئويروز را كاهش مى دهد ولى خطر استئوينى را كاهش نمى دهد(هَ). در مطالعه ى ديخر نشان داده شد كه ارتبـاط بـين BMI و BMD در مردان معنى دار ولى در زنان معنى دار نبوده اسـت(عس). عـلاوه بر آن محققين نشان دادند كه بين جاقى و استئويروز ارتباط معنى دارى وجود دارد و شانس تراكم استخوانى پايين در افـراد جـاق در مقايسه با نرمال 19٪\% كمتـر بـود ولى در مقايسـه BMD افـراد داراى اضافه وزن و افرادى كه وزن نرمـال داشـتند ارتبـاط معنسى

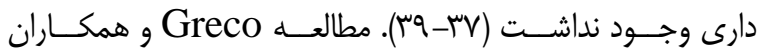
(سال • + (r) هم نشان داد كه با اضافه وزن توده استخوانى نرمـال يا محافظت شده داشتند در حالى كـهـ افـراد جـاقB BMD پـايينى داشتند كه با تشخيص استئويروز ساز كار بود(•). اكثر مطالعـات يافته هاى حاصل از اين مطالعه را تأييد مى كنند (أf - سأ). 


$$
\begin{aligned}
& \text { از محدوديت هاى اين مطالعه مى توان به محدود بـودن در يـى علاوه بر آن مى توان اين دو جنس را به صورت مقايسـه اى و در } \\
& \text { كلينيك اشاره نمود؛ اخر خه تمام زنان مراجعه كننده به اين مركزز مناطق جغرافيايى متفاوت مورد مطالعه قرار داد. } \\
& \text { مورد مطالعه قرار گرفتند با اين وجود كمبود حجم نمونه به عنوان }
\end{aligned}
$$

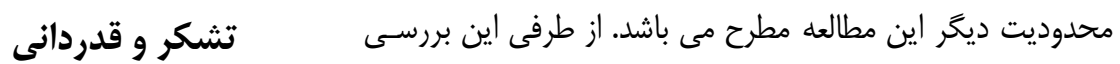

$$
\begin{aligned}
& \text { فقط زنان را شامل مى شود و گروه مردان در تحقيق لحـاظ نشـده با تشكر از برسنل محترم مركز كنترل كيفيت و سلامت بيمارستان }
\end{aligned}
$$

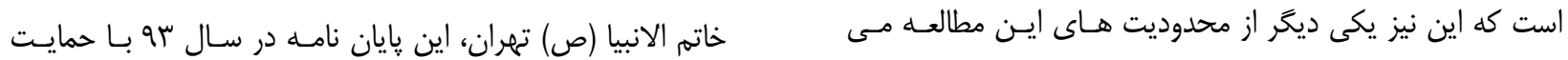

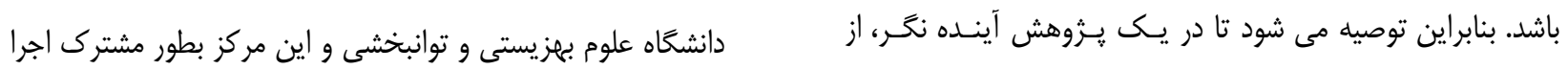

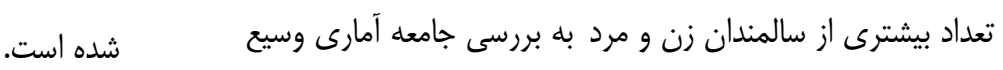

$$
\begin{aligned}
& \text { ترى از افراد و كروه هاى متفـاوت زنـان و مـردان يرداختـه شـود. }
\end{aligned}
$$

\section{- References}

1. Jamshidian-Tehrani M, Kalantari N, Azadbakht L,Esmaillzadeh A, Rajaei A, Houshiar$\operatorname{rad} \mathrm{A}$, et al.Osteoporosis risk factors in Tehrani women aged 40-60years. Iranian Journal of Endocrinology and Metabolism 2004; 6: 139-45.

2. Longo DL, Fauci AS, Kasper DL, Hauser SL, Jameson JL, Loscalzo J. Harrison's principles of internal medicine. 18th ed. New York: McGraw-Hill Co 2012; 3120-6.

3. Larijani B, Soltani A, Pajouhi M, Bastanhagh MH, Mirfezi Z, Dashti R, et al. Bone mineral density variations in 20-69 yr. population of Tehran/ Iran. Iranian South Medical Journal Boushehr Medical Science University 2005; 1: 41-9

4. Hirota T, Nara M, Ohguri M, Manago E, Hirota K. Effect of diet and lifestyle on bone mass in Asian young women. Am J ClinNutr 1992; 55: 1168-73.

5. Kameda T, Mano H, Yuasa T, et al. Estrogen inhibits bone resorption by directly inducing apoptosis of the bone resorbing osteoclasts. J Exp Med 1997;186(4):489- 95.

6. Whyte MP, Mumm S. Heritable disorders of the RANKL/OPG/RANK signaling pathway. J Musculoskelet Neuronal Interact 2004;4:254-67.

7. Roux S. New treatment targets in osteoporosis. Joint Bone Spine 2010;77:222-8.

8. Boyle WJ, Simonet WS, Lacey DL. Osteoclast differentiation and activation. Nature 2003;423:337-42. 
9. Reid IR. Relationships among body mass, its components, and bone. Bone 2002;31(5):547- 55 .

10. Rosen CJ, Bouxsein ML. Mechanisms of Disease: is osteoporosis the obesity of bone? Nat ClinPractRheumatol 2006;2(1):35-43.

11. Holecki M, Wiecek A. Relationship between body fat mass and bone metabolism. Pol Arch Med Wewn 2010;120 (9):361-67.

12. De Laet C, Kanis JA, Oden A, Johanson H, Johnell O, Delmas P, Eisman JA, Kroger H, Fujiwara S, Garnero P, McCloskey EV, Mellstrom D, Melton LJ, III, Meunier PJ, Pols HA, Reeve J, Silman A, Tenenhouse A. Body mass index as a predictor of fracture risk: A meta-analysis. Osteoporos Int. 2005;16:1330-1338

13. Barbour KE, Zmuda JM, Boudreau R, et al.; Health ABC Study. The effects of adiponectin and leptin on changes in bone mineral density. Osteoporos Int.2012; 23(6):1699-710.

14. Barbour KE, Zmuda JM, Boudreau R, et al. Adipokines and the risk of fracture in older adults. J Bone Miner Res.2011; 26(7):1568-76.

15. Smith DM, Nance WE, Kang KW, Christian JC, Johnston CC. Genetic factors in determining bone mass. J Clin Invest Yun AJ, Lee PY: Maladaptation of the link between inflammation and bone turnover may be a key determinant of osteoporosis. Med Hypotheses 2004, 63:532-537.

16. Zhao LJ, Liu YJ, Liu PY, Hamilton J, Recker RR, Deng HW. Relationship of obesity with osteoporosis. J ClinEndocrinolMetab. 2007;92:1640-1646

17. Hsu YH, Venners SA, Terwedow HA, Feng Y, Niu T, Li Z, Laird N, Brain JD, Cummings SR, Bouxsein ML, Rosen CJ, Xu X. Relation of body composition, fat mass, and serum lipids to osteoporotic fractures and bone mineral density in Chinese men and women. Am J ClinNutr. 2006;83:146-154

18. Faulkner, K.G., von Stetten, E., and Miller, P. Discordance in patient classification using T-scores. J Clin Densitom. 1999; 2: 343-350 
19. Baheiraei A, Pocock NA, Eisman JA, Nguyen ND, Nguyen TV. Bone mineral density, body mass index and cigarette smoking among Iranian women: implications for prevention. BMC MusculoskeletDisord 2005;6:34. Doi: 10.1186/1471-2474-6-34.

20. Zhao LJ, Liu YJ, Liu PY, Hamilton J, Recker RR, Deng HW. Relationship of obesity with osteoporosis. J ClinEndocrinolMetab 2007;92(5):1640-6.

21. Taaffe DR, Cauley JA, Danielson M, Nevitt MC, Lang TF, Bauer DC, Harris TB .Race and sex effects on the association between muscle strength, soft tissue, and bone mineral density in healthy elders: The health, aging, and body composition study. J Bone Miner Res. 2001;16(7):1343-52.

22. Bakker I, Twisk JW, Van Mechelen W, Kemper HC.Fat-free body mass is the most important body composition determinant of 10-yr longitudinal development of lumbar bone in adult men and women. J ClinEndocrinolMetab. 2003;88(6):2607-13.

23. MacInnis RJ, Cassar C, Nowson CA, Paton LM, Flicker L, Hopper JL, Larkins RG, WarkJD.Determinants of bone density in 30- to 65-year-old women: a co-twin study. J Bone Miner Res. 2003 Sep;18(9):1650-6.

24. Sharami SH, Millani F, Alizadeh A, et al. Risk factors of osteoporosis in women over 50 years of age: A population based study in the North of Iran. J Turkish-German GynecolAssoc 2008;9(9):38- 44.

25. Murillo-Uribe A, Aranda-Gallegos JE, Río de la Loza-Cava MF, Ortíz-Luna G, Mendoza-Torres LJ, Santos-González J. Relation between body mass index and bone mineral density in a sample population of Mexican women. GinecolObstet Mex1998;66:267-71.

26. Bener A, Hammoudeh M, Zirie M, Heller RF. Is obesity a protective factor for osteoporosis? J Rheumatol 2005;8: 32-8.

27. Paniagua MA, Malphurs JE, Samos LF. BMI and low bone mass in an elderly male nursing home population. ClinInterv Aging 2006;1(3):283-7.

28. Langlois A, Rosen C, Marian T. Association Between Insulin-Like Growth Factor I and Bone Mineral Density in Older Women and Men: The Framingham Heart Study,JCEM $.2013(4), 12-34$ 
29. Theill LE, Boyle WJ, Penninger JM. RANK-L and RANK: T cells, bone loss, and mammalian evolution. Annu Rev Immunol 2002;20:795-823.

30. Dougall WC, Glaccum M, Charrier K, Rohrbach K, Brasel K, De Smedt T, et al. RANK is essential for osteoclast and lymph node development. Genes Dev 1999;13:2412-24

31. Nakashima T, Hayashi M, Fukunaga T, Kurata K, Oh-Hora M, Feng JQ, et al. Evidence for osteocyte regulation of bone homeostasis through RANKL expression. Nat Med $2011 ; 17: 1231-4$

32. Yun TJ, Chaudhary PM, Shu GL, Frazer JK, Ewings MK, Schwartz SM, et al. OPG/FDCR-1, a TNF receptor family member, is expressed in lymphoid cells and is upregulated by ligating CD40. J Immunol 1998;161:6113-21.

33. Leibbrandt A, Penninger JM. RANK/RANKL: regulators of immune responses and bone physiology. Ann N Y Acad Sci 2008;1143:123-50.

34. Hughes AE, Ralston SH, Marken J, Bell C, MacPherson H, Wallace RG, et al. Mutations in TNFRSF11A, affecting the signal peptide of RANK, cause familial expansile osteolysis. Nat Genet 2000;24:45-8.

35. Andreoli A, Bazzocchi A, Celi M, et al. Relationship between body composition, body mass index and bone mineral density in a large population of normal, osteopenic and osteoporotic women. Radiol Med 2011;116 (7):1115-23.

36. Larijani B, HosseinNezhad A, Mojtahedi A, et al. Normative data of bone mineral density in healthy population of Tehran, Iran: A Cross sectional study. BMC MusculoskeletDisord 2005;6:38.

37. Fawzy T, Muttappallymyalil J, Sreedharan J, et al. Association between body mass Index and bone mineral density in patients referred for dual-energy x-ray absorptiometry scan in Ajman, UAE. J Osteoporosis 2011:4. doi:10.4061/2011/876309.

38. Cooper RR, Milgram JW, Robinson RA. Morphology of the osteon. An electron microscopic study. J Bone Joint Surg Am. 1966. 48(7):1239-71. 
39. Grabowski DC, Ellis JE. High body mass index does not predict mortality in older people: analysis of the longitudinal study of aging. J Am Geriatr ,2001. 49:968-979

40. Greco EA, Fornari R, Rossi F, et al. Is obesity protective for osteoporosis? Evaluation of bone mineral density in individuals with high body mass index. Int J ClinPract 2010;64 (6):817-20.

41. Pietrobelli.A, Faith.M.S, Allison.D.A, Gallagher.D, Chiomello .G."Body mass index as a measure of adiposity among children, adolescent and elderly, A validation study" .Journal of pediatrics, 1989 .132, pp:204- 210.

42. Zhu, S., Heo, M., Plankey, M., Faith, M.S., Allison, D.B. "Associations of body mass index and anthropometric indicators of fat mass and fat free mass with all-cause mortality among women in the first and second National Health and Nutrition Examination Surveys follow-up studies". Ann. Epidemiol.2003. 13,:286-293.

43. NIH Consensus Development Panel on Osteoporosis Prevention Diagnosis, and Therapy. Osteoporosis prevention, diagnosis, and therapy. JAMA. 2001;285:785-795

44. Haentjens P, Magaziner J , Colón-Emeric CS , Vanderschueren D , Milisen K , Velkeniers B , Boonen S 2010 Meta-analysis: excess mortality after hip fracture among older women and men. Ann Intern Med 152:380-390

45. Epstein S , Bryce G, Hinman JW , Miller ON , Riggs BL , Hui SL, Johnston CC 1986 The influence of age on bone mineral regulating hormones. Bone 7:421-425

46. Lips P. Vitamin D deficiency and secondaryhyperparathyroidism in the elderly:consequences for bone loss and fractures andtherapeutic implications. Endocr Rev $2001 ; 22: 477$.

47. Tóth E, Ferenc V, Mészáros S, Csupor E, Horváth C. Effects of body mass index on bone mineral density in men. Orv Hetil 2005;146(28):1489-93.

48. Silva HG, Mendonca LM, Conceicao FL, Zahar SE, Farias ML. Influence of obesity on bone density in postmenopausal women. Arq Bras EndocrinolMetabol 2007;51(6):94349. 
49. Maghraoui A, Guerboub AA, Mounach A, et al. Body mass index and gynecological factors as determinants of bone mass in healthy Moroccan women. Maturitas 2007;56 (4):375-82.

50. Shabani $\mathrm{m}$, ramazanpoor $\mathrm{m}$. the Relationship between the fat and lean body mass with lumbar spine bone mineral density in postmenopausal women. J North Khorasan Univ Med Sci. 2011

51. Parm AL, Saar M, Pärna K, Jürimäe J, Maasalu K, Neissaar I, Jürimäe T. Relationships between anthropometric, body composition and bone mineral parameters in 7-8-year-old rhythmic gymnasts compared with controls. Coll Antropol. 2011 Sep;35(3):739-45.

52. Taes YE, Lapauw B, Vanbillemont G, Bogaert V, De Bacquer D, Zmierczak H, Goemaere S, Kaufman JM.Fat mass is negatively associated with cortical bone size in young healthy male siblings. J Clin Endocrinol Metab. 2009;94(7):2325-31. 